\title{
Reliability and Validity Test of the Indonesian Version of the Nordic Musculoskeletal Questionnaire (NMQ) to Measure Musculoskeletal Disorders (MSD) in Traditional Women Weavers
}

\author{
Iwan Muhamad Ramdan, ${ }^{1}$ Krispinus Duma, ${ }^{2}$ Dina Lusiana Setyowati ${ }^{1}$ \\ ${ }^{1}$ Department of Occupational Health and Safety, Faculty of Public Health, Universitas Mulawarman, \\ Samarinda, Indonesia, ${ }^{2}$ Department of Public Health Sciences, Faculty of Medicine, \\ Universitas Mulawarman, Samarinda, Indonesia
}

\begin{abstract}
Musculoskeletal disorder remains to be a health and safety problem. One of measuring instrument often use to assess musculoskeletal disorders worldwide is the Nordic musculoskeletal questionnaire (NMQ). This questionnaire translated into various languages and tested for its validity and reliability. However, it has limitations, such as the difficulty of application in countries that do not speak English. This study aims to test the validity and reliability of the Indonesian version of NMQ in women weavers working using traditional handlooms in East Kalimantan Indonesia from March to May 2018. The validity of items obtained ranges 0.501 (min.) to 0.823 (max.), and Cronbach's alpha reliability was 0.726 . In conclusion, the NMQ in Indonesian version has satisfactory psychometric properties with adequate validity and reliability.
\end{abstract}

Key words: Musculoskeletal disorders, NMQ in Indonesian, reliability, validity

\section{Uji Validitas dan Reliabilitas Nordic Musculoskeletal Questionnaire (NMQ) Versi Indonesia untuk Mengukur Gangguan Muskuloskeletal pada Penenun Tradisional Wanita}

\begin{abstract}
Abstrak
Gangguan muskuloskeletal masih menjadi masalah kesehatan dan keselamatan kerja. Salah satu alat ukuryang sering dipakai untuk mengkaji gangguan muskuloskeletal di seluruh dunia adalah Nordic musculoskeletal questionnaire (NMQ). Kuesioner ini telah diterjemahkan ke berbagai bahasa di dunia dan terbukti valid serta reliabel, tetapi memiliki keterbatasan di antaranya sulit diaplikasikan di negara yang tidak menggunakan bahasa Ingris sebagai bahasa sehari-hari. Penelitian ini bertujuan menguji validitas dan reliabilitas NMQ versi bahasa Indonesia pada penenun tradisional wanita di Kalimantan Timur periode Maret sampai Mei 2018. Didapatkan hasil uji validitas item berkisar antara 0,501 (min.) sampai 0,823 (maks.) dan indeks reliabilitas Cronbach's alpha sebesar 0,726. Simpulan, NMQ versi bahasa Indonesia cukup valid dan reliabel untuk mengukur gangguan muskuloskeletal.
\end{abstract}

Kata kunci: Gangguan muskuloskeletal, NMQ berbahasa Indonesia, reliabilitas, validitas 


\section{Introduction}

Musculoskeletal disorders (MSD) is a condition that can affect any part of the musculoskeletal system. It includes the muscles, bones, nerves, joints and spinal discs, along with supporting blood vessels and connective tissues such as tendons, ligaments, and cartilage. The symptoms, including pain, numbness, tingling, aching, stiffness, or burning. ${ }^{1,2}$ Musculoskeletal disorders have become increasingly prevalent worldwide during the past decade. ${ }^{3}$ It not only affects the workers' quality of life but also imposes a significant economic burden to the society. ${ }^{4}$ It also has a high health cost, and it constitutes a significant cause of occupational injury and physical disability in both developed and developing countries. ${ }^{5}$

MSD occurs in various industries, both formal and informal sectors. High-risk occupation including construction, agriculture, manufacturing, wholesale and retail trade, and human health and social work. ${ }^{5}$ Risk factors related to MSD include heavy physical work, forceful overexertion, awkward and sustained postures, repetitive movement, and vibration. ${ }^{6} \mathrm{~A}$ systematic review by da Costa and Vieira ${ }^{7}$ proposed that several biomechanical, psychosocial, and individual factors contributed to the occurrence of work musculoskeletal disorders (WMSD).

The syndrome of musculoskeletal work disorders includes pain and stiffness in various regions of the body like neck, shoulder, lower back, wrist, hand, and fingers. ${ }^{8}$ Based on various typical complaints, experts have compiled various instruments/questionnaires to examine the subjective complaints of WMSD. ${ }^{9}$ One of measuring instrument that is often used to assess musculoskeletal disorders worldwide is the Nordic musculoskeletal questionnaire (NMQ). With the support of the Nordic Council of Minister, the NMQ developed to create a simple, standardized questionnaire. It should be able to be used to detect and analyze musculoskeletal symptoms of different individuals in different parts of the body..$^{10}$

The NMQ has several advantages over other measuring instruments. Some of them are: standardized questions, worldwide recognition, its free, provide self-evaluation, and relatively quick identification of the symptoms. It also has applicability in large populations and frequent use together with other evaluation methods such as rapid upper limb assessment (RULA), rapid entire body assessment (REBA) and Ovako working posture analysis system (OWAS). However, NMQ also has limitations, among them is the difficulty of application in countries that do not speak English (for errors in translation, interpretation, and or validation) and restriction of exhaustive questions to three areas of the body (lower back, neck, and shoulders). ${ }^{11}$

The NMQ has been translated into various languages and occupation and tested for its validity and reliability.,4,12-16 However, the literature that discusses the results of the NMQ translation, validity, and reliability test in the Indonesian version is still limited. This study aims to simplification and translating NMQ into the Indonesian version. The make the NMQ accessible for the use in the Indonesian setting. Its validity and reliability tested in women weavers working using traditional handlooms in East Kalimantan Indonesia.

\section{Methods}

The study was on 50 "Samarinda Sarong" women weavers who work using traditional handlooms in Samarinda, East Kalimantan, Indonesia from March to May 2018. The traditional weaving "Samarinda Sarong" is one of Samarinda city tourism icons, which until now maintained because it is considered to have artistic value and high origin.

The $\mathrm{NMQ}^{10}$ is in two well-differentiated structures. The first part, the general one, refers to symptoms in 9 parts of the body (neck, shoulders, elbows, wrists/hands, upper back, lower back, hip/thighs, knees, and ankles/feet) during the last 12 months/7 days. The second part, the specific one, refers to symptoms in three parts of the body (neck, shoulders, and lower back) throughout the subject's working life/7 days beforehand. To answer this questionnaire, the subjects were asked to answer "yes" or "no" to the following question: "Have you any time during the last 12 months had trouble (ache, pain, discomfort) infollowed by a list and body diagram of the nine different anatomical areas. If the respondent marked "yes", then the respondent was asked to answer the question "Have you at any time during the last 12 months been prevented from doing your normal work (at home or away from home) because of the trouble?" and "Have you any trouble at any time during the last 7 days?" (Figure 1).

Data were analyzed by the Statistical Package 
for the Social Sciences (SPSS) ver. 21, in order to describe continuous and qualitative variables, mean, standard deviation (SD) and percentage frequency used respectively.

Pearson product-moment correlation used to evaluate the construct validity of the total score of the NMQ per questionnaire is an association with the baseline. NQM Indonesian version considered as 'good to excellent' when $r \geq 0.75$, as 'good' when $\mathrm{r}$ ranged between 0.5 and 0.7 , as 'fair' when $\mathrm{r}$ ranged between 0.25 and 0.50 , and as 'little or no relationship' when $r$ was less than 0.25. Cronbach's alpha intraclass coefficient and the 95\% confidence interval (CI) of the point estimation calculated for the whole questionnaire. Cronbach's alpha values $>0.70$ were considered satisfactory. ${ }^{17-20}$

The study was reviewed and approved by the Health Research Ethics Committee, Faculty of Medicine, Universitas Mulawarman, Samarinda with letter number: 33/KEPK-FK/IV/2018. Informed written consent requested from the participants before their participation.

\section{Results}

The majority of respondents in this study were
$>46-56$ years old (34\%), the majority of marital status were married (96\%), education level is mostly elementary school (graduated $6^{\text {th }}$ grade) (62\%), most of the working experience is more than 5 years $(80 \%)$ and working time is mostly $>5^{-8}$ hours per day (76\%) (Table 1 ).

In this study, the NQM original version simplified from the type of chain question to a single question ("Have you at any time during the last 12 months had trouble (ache, pain, discomfort) in"). Whereas, the answer option was changed from "yes" or "no" to a rating with 4 scales, i.e., no pain (A) (scale o), moderate pain (B) (scale 1), pain (C) (scale 2) and very sick (D) (scale 3). The 28 body regions studied consist of: upper neck, lower neck, left shoulder, right shoulder, left upper arm, back, right upper arm, waist, buttock, bottom, left elbow, right elbow, left lower arm, right lower arm, left wrist, right wrist, left hand, right hand, left thigh, right thigh, left knee, right knee, left calf, right calf, left ankle, right ankle, left foot and right foot.

The question of NMQ and the 28 items/ body region of NMQ translated into Indonesian from the English format producing three separate Indonesia version: one proposed by the author, one by a general medical practitioner,

Table 1 Respondents Characteristics

\begin{tabular}{|c|c|c|}
\hline Variables & Number $(n=50)$ & Percentage \\
\hline \multicolumn{3}{|l|}{ Age (years) } \\
\hline $28-34$ & 10 & 20 \\
\hline$>34-40$ & 8 & 16 \\
\hline$>40-46$ & 7 & 14 \\
\hline$>46-56$ & 17 & 34 \\
\hline$>56-70$ & 6 & 12 \\
\hline$>70$ & 2 & 4 \\
\hline \multicolumn{3}{|l|}{ Marital status } \\
\hline Not married & 2 & 4 \\
\hline Married & 48 & 96 \\
\hline \multicolumn{3}{|l|}{ Education background } \\
\hline Never went to school/did not graduate elementary school & 10 & 20 \\
\hline Elementary school (graduated $6^{\text {th }}$ grade) & 31 & 62 \\
\hline Secondary high school (graduated $9^{\text {th }}$ grade) & 6 & 12 \\
\hline Senior high school (graduated $12^{\text {th }}$ grade) & 3 & 6 \\
\hline \multicolumn{3}{|l|}{ Working experience (years) } \\
\hline$<5$ & 11 & 20 \\
\hline$>5$ & 39 & 80 \\
\hline \multicolumn{3}{|l|}{ Working time per day (hours) } \\
\hline $3-5$ & 9 & 18 \\
\hline$>5^{-8}$ & 38 & 76 \\
\hline$>8-10$ & 3 & 6 \\
\hline
\end{tabular}




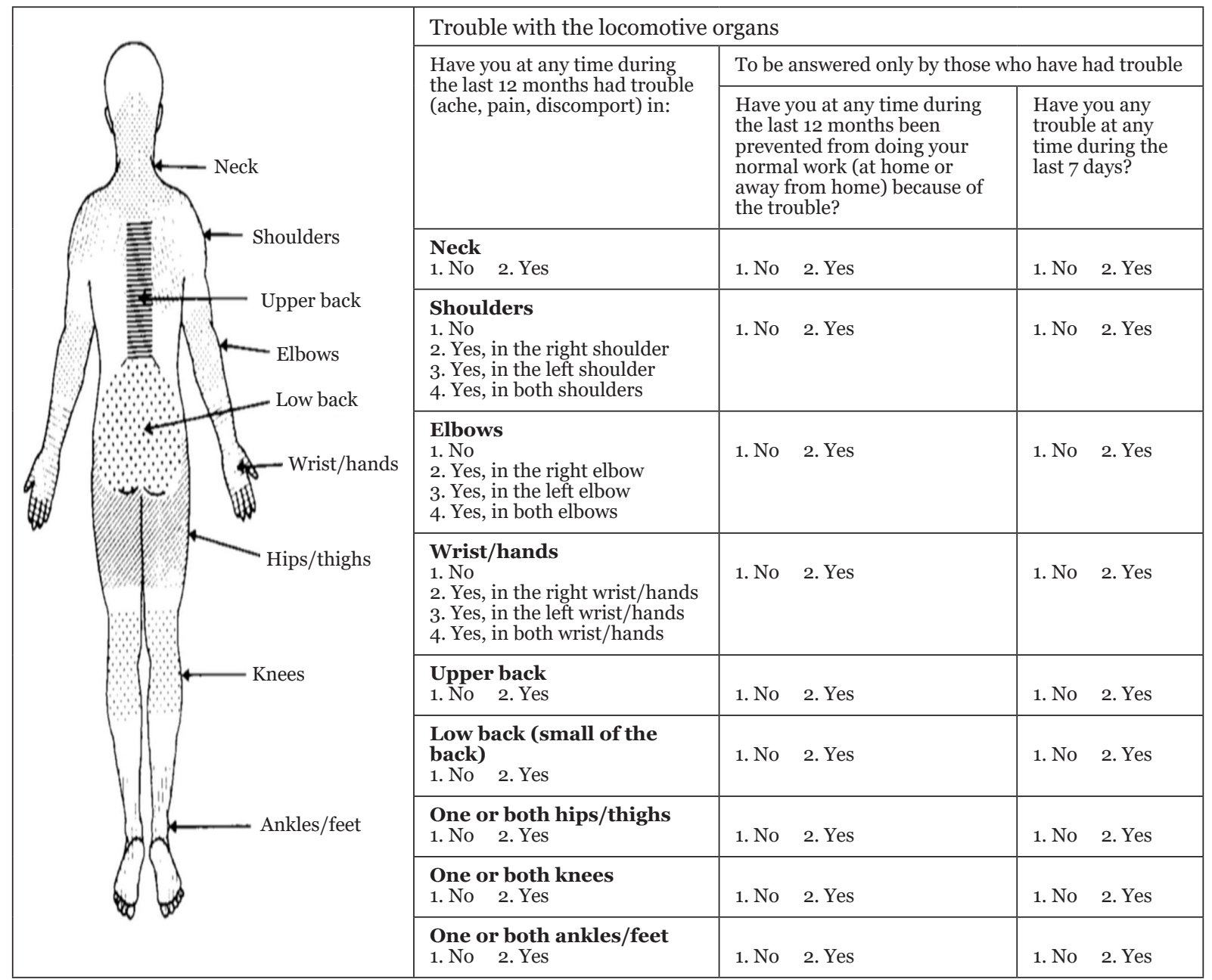

Figure 1 Original Version of Nordic Musculoskeletal Questionnaire (NMQ)

and another by English language expert from Language Laboratory. After going through the analysis/review of content aspects and grammar, three separate translations produced to one single Indonesian version. The final results of the NMQ simplification and translation into Indonesian is in Figure 2.

As shown in Table 2, the mean of the total NMQ score was $15.94( \pm 8.17)$. The highest score is from $9^{\text {th }}$ item on "Bottom" $(1.62), 8^{\text {th }}$ item on "Buttock" (1.58) and item number o on "upper neck" (o.86). The lowest score is from $13^{\text {th }}$ item on the "Right lower arm" (0.12), $7^{\text {th }}$ item on "Waist" (o.14) and $12^{\text {th }}$ item on "Left lower arm" (o.16). The most significant variance observed in item 7 "Waist" (1.266), item 9 "Bottom" (1.138), and item 5 "Back" (1.102); while the smallest variance observed in item 12 "Left lower arm" (0.21). The smallest Pearson correlation is from item number
12 on "Left lower arm" (0.501), item number 10 on "Left elbow" (0.503), and item number 3 on "Right shoulder" (0.510). The highest Pearson correlation is from item number 8 on "Buttock" (o.823), item number 7 on "Waist" (0.752), and item number 5 on "Back" (o.689).

As shown in Table 2 and Figure 1, the Cronbach's alpha as an internal consistency range from 0.707 (lowest) to 0.728 (highest). There are several alternatives to increase the Cronbach's alpha coefficient. With question number 8 "Buttock" deleted this can increase Cronbach's alpha coefficient by 0.726 . If question number 10 "Body region of the left elbow" deleted this can increase Cronbach's alpha coefficient by 0.727 and if item question number 11 "Body region of the right elbow" deleted this can increase Cronbach's alpha coefficient by 0.728 . However, in general, the combination of all 28 items/ 


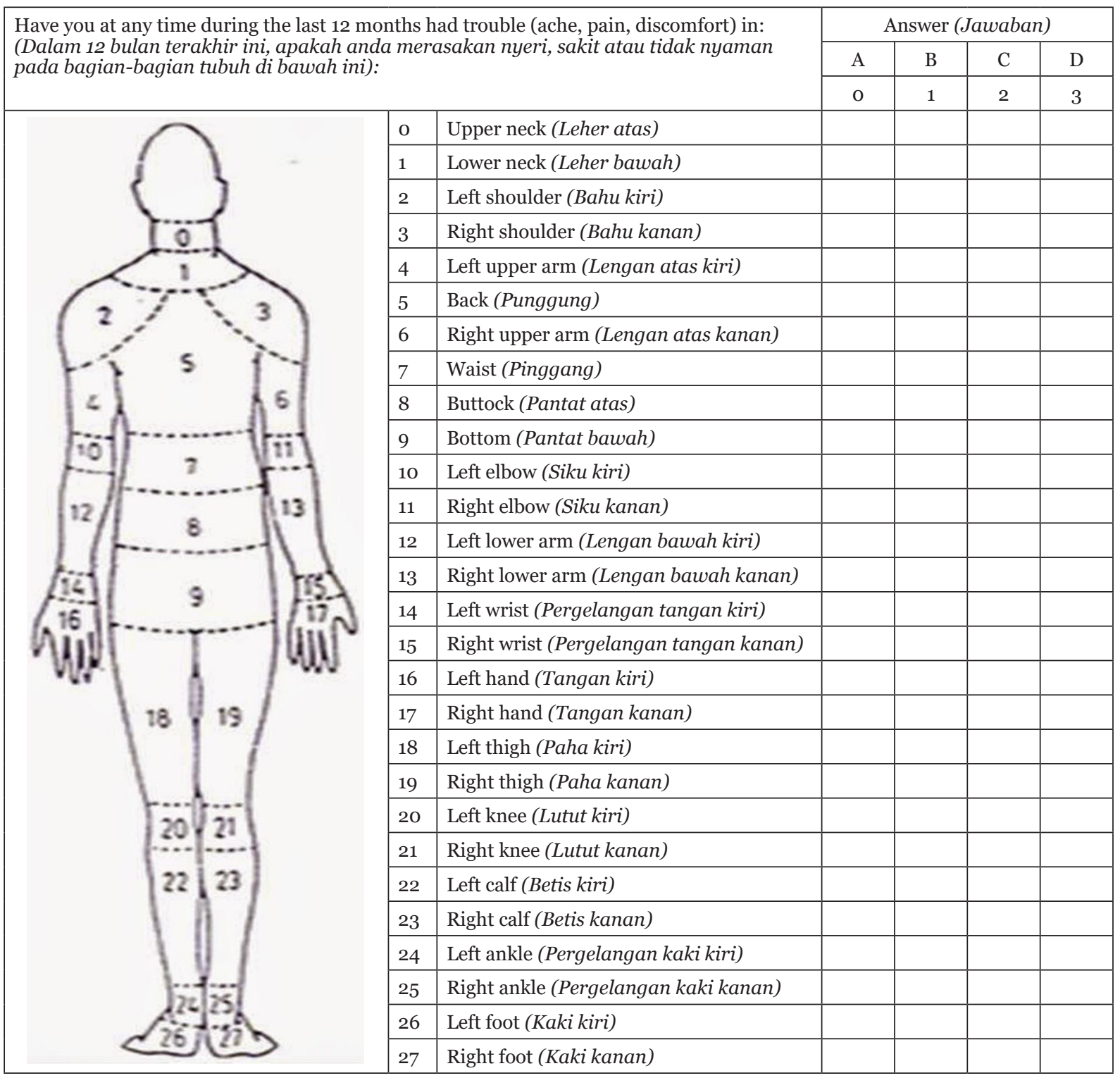

Figure 2 Simplification of the NMQ and Translation into Indonesian Version

body region showed the highest reliability with Cronbach's alpha coefficient of 0.726 (Figure 3). This result generally shows that the Indonesian version of NMQ is reliable to measure MSD.

Based on Table 2 and the previous criteria, the results of the Pearson correlation showed the item number 7 and 8 declared are "excelent" because Pearson correlation (r) more than 0.75, and item number $0,1,2,3,4,5,6,9,10,11,12,13$, $14,15,16,17,18,19,20,21,22,23,24,25,26,27$ declare are "good" because Pearson correlation (r) ranged from 0.5 to 0.7 .

In general, all of the questions are valid to measure MSD in traditional women weavers.

\section{Discussion}

The questionnaire, as one of the measuring instruments, must be valid and reliable. Validity measured what is intended to be measured, explains how well the collected data covers the actual area of investigation, and expresses the degree to which a measurement measures what it purports to measure. Reliability concerns the extent to which a measurement of a phenomenon provides stable and consist result, and also 
Table 2 Descriptive Characteristics, Cronbach's Alpha Reliability, and the Pearson Correlation of Each Data for Internal Consistency of Indonesian Version of the NMQ $(n=50)$

\begin{tabular}{|c|c|c|c|c|c|c|c|}
\hline $\begin{array}{l}\text { Item/Body } \\
\text { Region }\end{array}$ & Mean & SD & Variance & $\mathbf{r}$ & p Value & $\begin{array}{c}\text { Corrected } \\
\text { Item/Total } \\
\text { Correlation }\end{array}$ & $\begin{array}{c}\text { Cronbach's } \\
\text { Alpha if Item } \\
\text { Deleted }\end{array}$ \\
\hline Item o & 0.86 & 0.948 & 0.898 & 0.576 & 0.007 & 0.153 & 0.724 \\
\hline Item 1 & 0.74 & 0.899 & 0.809 & 0.573 & 0.055 & 0.383 & 0.718 \\
\hline Item 2 & 0.66 & 0.772 & 0.596 & 0.542 & 0.032 & 0.355 & 0.718 \\
\hline Item 3 & 0.66 & 0.717 & 0.515 & 0.510 & 0.010 & 0.351 & 0.719 \\
\hline Item 4 & 0.46 & 0.762 & 0.580 & 0.570 & 0.058 & 0.444 & 0.716 \\
\hline Item 5 & 0.80 & 1.050 & 1.102 & 0.689 & 0.000 & 0.487 & 0.713 \\
\hline Item 6 & 0.40 & 0.782 & 0.612 & 0.535 & 0.031 & 0.404 & 0.717 \\
\hline Item 7 & 0.14 & 1.125 & 1.266 & $0.75^{2}$ & 0.000 & 0.570 & 0.710 \\
\hline Item 8 & 1.58 & 0.971 & 0.942 & 0.832 & 0.000 & 0.093 & 0.726 \\
\hline Item 9 & 1.62 & 1.067 & 1.138 & 0.619 & 0.024 & 0.494 & 0.713 \\
\hline Item 10 & 0.26 & 0.751 & 0.564 & 0.503 & 0.015 & 0.007 & 0.727 \\
\hline Item 11 & 0.18 & 0.560 & 0.314 & 0.517 & 0.022 & -0.041 & 0.728 \\
\hline Item 12 & 0.16 & 0.468 & 0.219 & 0.501 & 0.016 & 0.534 & 0.715 \\
\hline Item 13 & 0.12 & 0.328 & 0.108 & 0.586 & 0.006 & 0.561 & 0.714 \\
\hline Item 14 & 0.28 & 0.607 & 0.369 & 0.664 & 0.001 & 0.368 & 0.720 \\
\hline Item 15 & 0.18 & 0.482 & 0.232 & 0.577 & 0.007 & 0.439 & 0.719 \\
\hline Item 16 & 0.52 & 0.839 & 0.704 & 0.521 & 0.023 & 0.290 & 0.721 \\
\hline Item 17 & 0.40 & 0.670 & 0.449 & 0.635 & 0.002 & 0.326 & 0.721 \\
\hline Item 18 & 0.58 & 0.785 & 0.616 & 0.615 & 0.003 & 0.571 & 0.712 \\
\hline Item 19 & 0.54 & 0.762 & 0.580 & 0.563 & 0.056 & 0.573 & 0.712 \\
\hline Item 20 & 0.52 & 0.814 & 0.663 & 0.530 & 0.012 & 0.233 & 0.723 \\
\hline Item 21 & 0.48 & 0.789 & 0.662 & 0.680 & 0.000 & 0.232 & 0.723 \\
\hline Item 22 & 0.66 & 0.848 & 0.719 & 0.659 & 0.001 & 0.683 & 0.707 \\
\hline Item 23 & 0.56 & 0.787 & 0.619 & 0.662 & 0.001 & 0.689 & 0.707 \\
\hline Item 24 & 0.36 & 0.563 & 0.317 & 0.661 & 0.001 & 0.286 & 0.725 \\
\hline Item 25 & 0.32 & 0.471 & 0.222 & 0.697 & 0.000 & 0.238 & 0.724 \\
\hline Item 26 & 0.46 & 0.706 & 0.498 & 0.690 & 0.000 & 0.524 & 0.715 \\
\hline Item 27 & 0.44 & 0.675 & 0.456 & 0.699 & 0.000 & 0.530 & 0.715 \\
\hline Total score & 15.94 & 8.17 & 66.751 & 1 & - & 1.000 & 0.834 \\
\hline
\end{tabular}

the degree to which the results obtained by measurement and the procedure can be replicated. ${ }^{21,22}$

The finding indicates that the NMQ in Indonesian version has satisfactory psychometric properties with adequate validity and reliability. It can be used to measure MSD on traditional women weavers. Similar to this study, several efforts translating NMQ into other language is Legault et al. ${ }^{10}$ concluded that the French adapted version of the NMQ-E is an appropriate self-administered musculoskeletal symptom screening tool for the adolescent population. Arsalani et al. ${ }^{23}$ concluded that adaptation of the NMQ in Iranian version has an acceptable conceptual structure and provides reliable information to measure health condition
(MSD) in Iranian nursing personnel. Mesquita et al. ${ }^{14}$ concluded the Portuguese version of the standardized Nordic musculoskeletal questionnaire seems to be valid and revealing good coefficients of reliability to measure MSD in food distribution workers in Portuguese. de Barros and Alexandre ${ }^{24}$ concluded that the Brazilian version of the standardized Nordic questionnaire has a firm agreement and substantial reliability. Kahraman et al. ${ }^{16}$ argued the Turkish version of the NMQ has appropriate psychometric properties, including good test-retest reliability, internal consistency and construct validity, and can be used for screening and epidemiological investigations of musculoskeletal symptoms. Alaca $^{25}$ stated that the Turkish version of the 


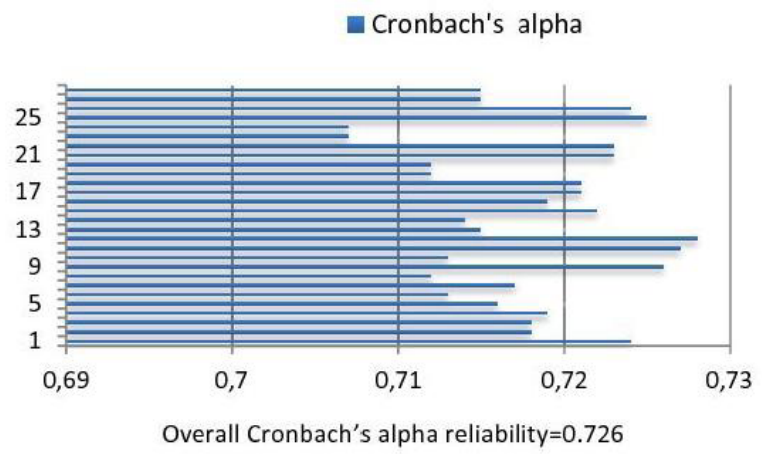

Figure 3 Result of Overall Cronbach's Alpha Reliability Test

NMQ-E showed adequate internal consistency (Cronbach coefficient $\alpha=0.78$ ).

\section{Conclusion}

The study demonstrates that translating of the NMQ into the Indonesian language fulfills the criteria of a reliable and valid assessment tool to rate the MSD. The high internal consistency and construct validity support the application of the NMQ as an easily administered tool to assess MSD in the Indonesian setting.

\section{Conflict of Interest}

The author declare no conflict of interest.

\section{Acknowledgments}

The authors are very grateful to all traditional women weavers participated in this study. This research funded by the Directorate General of Higher Education, Ministry of Research, Technology and Higher Education of the Republic of Indonesia.

\section{References}

1. Shariat A, Mohd Tamrin SB, Arumugam M, Danaee M, Ramasamy R. Musculoskeletal disorders and their relationship with physical activities among office workers: a review. MJPHM. 2016;16(1):62-74.

2. Sirajudeen MS, Alaidar $\backslash$ ous M, Waly M, Alqahtani M. Work-related musculoskeletal disorders among faculty members of college of Applied Medical Sciences,
Majmaah University, Saudi Arabia: a crosssectional study. Int $\mathrm{J}$ Health Sci (Qassim). 2018;12(4):18-25.

3. Gasibat Q, Simbak NB, Aziz AA. Stretching exercises to prevent work-related musculoskeletal disorders-a review article. AJSSM. 2017;5(2):27-37.

4. Wang J, Cui Y, He L, Xu X, Yuan Z, Jin X, et al. Work-related musculoskeletal disorders and risk factors among Chinese medical staff of obstetrics and gynecology. Int $\mathrm{J}$ Environ Res Public Health. 2017;14(6). pii: E562.

5. Park J, Kim Y, Han B. Work sectors with high risk for work-related musculoskeletal disorders in Korean men and women. Saf Health Work. 2018;9(1):75-8.

6. Feng Q, Liu S, Yang L, Xie M, Zhang Q. The prevalence of and risk factors associated with musculoskeletal disorders among sonographers in central China: a cross-sectional study. PLoS One. 2016;11(10):e0163903.

7. da Costa BR, Vieira ER. Risk factors for work-related musculoskeletal disorders: a systematic review of recent longitudinal studies. Am J Ind Med. 2010;53(3):285-323.

8. Iti JL, Nigudgi SR, Reddy S. Assessment of musculoskeletal disorders by standardized nordic questionnaire among computer engineering students and teaching staff of Gulbarga city. Int J Community Med Public Health. 2016;3(3):668-74.

9. Salleh NFM, Sukadarin EH, Zakaria J. Preliminary study of musculoskeletal complaints and ergonomic risk factors. APEOHJ. 2017;3(1):39-43.

10. Legault EP, Cantin V, Descarreaux M. Assessment of musculoskeletal symptoms and their impacts in the adolescent population: adaptation and validation of a questionnaire. BMC Pediatr. 2014;14:173.

11. López-Aragón L, López-Liria R, CallejónFerre ÁJ, Gómez-Galán M. Applications of the standardized Nordic questionnaire: a review. Sustainability. 2017;9(9):1514.

12. Gupta G, Bhavana, Rishikesh. Reliability and validity of Hindi version of Nordic musculoskeletal questionnaire. EC Orthop. 2018;9(8):533-8.

13. Dawson AP, Steele EJ, Hodges PW, Stewart S. Development and test-retest reliability of an extended version of the Nordic musculoskeletal questionnaire (NMQ-E): a 
screening instrument for musculoskeletal pain. J Pain. 2009;10(5):517-26.

14. Mesquita CC, Ribeiro JC, Moreira P. Portuguese version of the standardized Nordic musculoskeletal questionnaire: cross cultural and reliability. J Public Health Springer Verlag. 2010;18(5):461-6.

15. Namnik N, Negahban H, Salehi R, Shafizadeh R, Tabib MS. Validity and reliability of Persian version of the specific Nordic questionnaire in Iranian industrial workers. Work. 2016;54(1):35-41.

16. Kahraman T, Genç A, Göz E. The Nordic musculoskeletal questionnaire: crosscultural adaptation into Turkish assessing its psychometric properties. Disabil Rehabil. 2016;38(21):2153-60.

17. Alsous M, Alhalaiqa F, Abu Farha R, Abdel Jalil M, McElnay J, Horne R. Reliability and validity of Arabic translation of medication adherence report scale (MARS) and beliefs about medication questionnaire (BMQ)specific for use in children and their parents. PLoS One. 2017;12(2):e0171863.

18. Alamam DM, Leaver A, Moloney N, Alsobayel HI, Alashaikh G, Mackey MG. Pain behaviour scale (PaBS): an exploratory study of reliability and construct validity in a chronic low back pain population. Pain Res Manag. 2019;2019:2508019.

19. Tavakol M, Dennick R. Making sense of Cronbach's alpha. Int $\mathrm{J}$ Med Educ.
2011;2:53-5.

20. Michalopoulos LTM, Murray LK, Kane JC, Skavenski van Wyk S, Chomba E, Cohen $\mathrm{J}$, et al. Testing the validity and reliability of the shame questionnaire among sexually abused girls in Zambia. PLoS One. 2015;10(4):e0123820.

21. Taherdoost H. Validity and reliability of the research instrument; how to test the validation of a questionnaire/survey in a research. IJARM. 2016;5(3):28-36.

22. Bolarinwa OA. Principles and methods of validity and reliability testing of questionnaires used in social and health science researchers. Niger Postgrad Med J. 2015;22(4):195-201.

23. Arsalani N, Fallahi-Khoshknab M, Ghaffari M, Josephson M, Lagerstrom M. Adaptation of questionnaire measuring working conditions and health problems among Iranian nursing personnel. Asian Nurs Res (Korean Soc Nurs Sci). 2011;5(3):177-82.

24. de Barros EN, Alexandre NM. Cross-cultural adaptation of the Nordic musculoskeletal questionnaire. Int Nurs Rev. 2003;50(2):1018.

25. Alaca N, Safran EE, Karamanlargil Aİ, Timucin E. Translation and cross-cultural adaptation of the extended version of the Nordic musculoskeletal questionnaire into Turkish. J Musculoskelet Neuronal Interact. 2019;19(3):1-10. 